\title{
Peran Guru dan Orangtua Dalam Mengatasi Kesulitan Belajar Matematika Anak Slow Learner di Masa Pandemi Covid-19
}

\section{Isnaini Handayani ${ }^{1 *}$, Allafta Muhsinatin Al-Farhatan Noor Asri2}

\author{
1,2 Pendidikan Matematika, Universitas Muhammadiyah Prof. Dr. HAMKA, Jakarta Timur, Indonesia
}

\section{A R T I C L E I N F O}

\section{Article history:}

Received May 22, 2021

Revised May 23, 2021

Accepted June 24, 2021

Available online July 25, 2021

Kata Kunci:

Peran Guru, Orang Tua, Slow Learner

Keywords:

The Role Of Teachers And Parents, Slow Learners

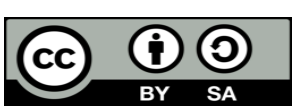

This is an open access article under the CC BY-SA license.

Copyright (C) 2021 by Author.

Published by Universitas Pendidikan Ganesha.

\begin{abstract}
A B S T R A K
Saat ini hasil belajar anak belum bisa dikatakan berhasil secara optimal dimana bagi anak slow learner, pembelajaran daring bukanlah solusi yang baik. hal ini didukung oleh tidak semua orang tua dan guru berperan secara optimal. Masalah ini menjadi salah saru alasan penelitian yang bertujuan untuk mengkaji peran guru dan orang tua dalam mengatasi kesulitan belajar matematika anak slow learner di masa pandemi covid-19. Jenis penelitian yang digunakan oleh peneliti adalah kualitatif, dengan desain penelitian yang digunakan merupakan kualitatif deskriptif. Subjek penelitian digunakan peneliti ada 3 yaitu satu guru mata pelajaran .matematika, satu orangtua anak ABK, dan satu kepala sekolah. Mengunakan wawancara online dan metode observasi untuk mengumpulkan data. Teknik analisis data yang digunakan adalah penyederhanaan data, penyajian data dan penarikan kesimpulan. Hasil penelitian ini menunjukkan bahwa peran guru yakni adanya perlakuan khusus di kelas, guru selalu memantau tugas-tugas anak slow learner, dan adanya video pembelajaran matematika yang di kirimkan oleh guru via whatsapp.. Adapun peran orang tua yakni merupakan pendidik bagi anak, orangtua sebagai pelindung anak, anak prioritas orangtua, dan orangtua mengetahui kondisi anak ketika di rumah. Adapun peran kepala sekolah yakni kepala sekolah membimbing guru dalam proses pembelajaran, dan adanya evaluasi untuk guru. Kesimpulan dari penelitian ini bahwa guru, orangtua, dan kepala sekolah sangatlah berpengaruh dalam mengatasi kesulitan belajar anak slow learner.
\end{abstract}

\begin{abstract}
A B S T R A C T
Currently, children's learning outcomes cannot be said to be optimally successful, where for slow learners, bold learning is a good solution. this is supported by not all parents and teachers play an optimal role. This problem is one of the reasons for research that aims to examine the role of teachers and parents in overcoming difficulties in learning mathematics for slow learner children during the COVID-19 pandemic. The type of research used by the researcher is qualitative, with the research design used is descriptive qualitative. There are 3 research subjects used by researchers, namely one teacher of mathematics, one parent of children with special needs, and one principal. Use online interviews and observation methods to collect data. The data analysis technique used is data simplification, data presentation and conclusion drawing. The results of this study indicate that the role of the teacher is the existence of special treatment in the classroom, the teacher always unites the tasks of the slow learner, and the existence of a mathematics learning video presented by the teacher via whatsapp. The role of parents is as an educator for children, parents as protectors of children, children are the priority of parents, and parents know the condition of children when they are at home. The role of the principal, namely the principal, guides teachers in the learning process, and evaluates teachers. The conclusion from this study is that teachers, parents, and school principals have no effect in overcoming the learning difficulties of slow learner children.
\end{abstract}

\section{PENDAHULUAN}

Pandemic covid-19 menyebabkan terjadinya perubahan tatanan kehidupan manusia dalam segala minat (Chang et al., 2020; Mokter, 2020; Remuzzi \& Remuzzi, 2020; Wong et al., 2020). Salah satu peminat yang sangat dipengaruhi yakni minat pembelajaran (Panesar et al., 2020). Dampak pandemic ini sangat dirasakan oleh semua kalangan belajar, proses pembelajaran yang dilakukan secara tatap muka harus digeser dengan pembelajaran online untuk mencegah terjadinya penyeberan Covid-19 (Khachfe et al., 2020) serta segala kegiatan seperti seminar, lokakarya, koferensi dan kegiatan lainya ditunda bahkan dibatalkan (Mishra et al., 2020; Oyedotun, 2020; Patricia, 2020; Sahu, 2020). Dimasa pandemic covid-19 proses pembelajaran jarak jauh merupakan pembelajaran yang baik, karena pandemic covid-19 ini proses pembelajaran jarak jauh menjadi bahan pembicaraan didalam masyarakat, dan menjadi pro kontra didalam masyarakat mengenai efektif dan tidak efektif untuk anak (Edwards et al., 2012). Wawasan yang bertentangan tumbuh dari beberapa pendapat pakar pendidikan, dengan keadaan pembelajaran jarak 
jauh akan menolong anak murid untuk mengetahui bahan materi pembelajaran yang bersifat tidak berwujud, meningkatkan pembelajaran yang kongregasi, pikiran dan kegiatan mengatasi masalah (Arnott \& Yelland, 2020). Pembelajaran jarak jauh merupakan pembelajaran yang efektif di masa pandemic ini, selain waktu yang banyak untuk mengerjakan soal, siswa dapat latihan soal lebih banyak di rumah, dan orangtua dapat mengkondisikan anak ketika pembelajaran jarak jauh dilaksanakan (Hwang et al., 2020; Kkese, 2020; Lage-Cala et al., 2020).

Pembelajaran jarak jauh tidak selamanya memberikan dampak yang positif, bagi beberapa anak yang mengalami keterlambatan/kesulitan dalam proses belajar, pembelajaran daring bukanlah solusi yang tepat digunakan. Selain itu malah pembelajaran daring yakni tidak semua anak mempunyai fasilitas yang sama dalam proses pembelajaran. Serta, pembelajaran daring berakibat terhadap transformasi perilaku arestasi social, kurangnya kualitas, keikutsertaan serta keterbatasan umpan balik. Orang tua belum siap untuk mengalami pembelajaran jarak jauh, pembelajaran jarak jauh tidak memiliki suasana resmi pembelajaran tradisional, dan tidak ada interaksi sosial antar siswa dalam pembelajaran jarak jauh (Dong et al., 2020). Adanya game online, dan media online yang lain membuat siswa menjadi candu dalam bermain game dan media online, mengakibatkan pembelajaran yang berjalan tidak efektif (Liu, 2020; Samaha \& Hawi, 2016). Serta masalah yang lainnya dengan pemberian masalah yang terlalu rumit dapat menyebabkan peserta didik frustasi dan tidak ingin belajar. Kondisi ini membuat anak kesulitan belajar yang berdampak terhadap hasil belajar.

Kesulitan belajar yang dialami anak murid selama masa pandemic covid-19 yakni pelaksanaan belajar mengajar di rumah, karena anak murid merasa tertekan saat belajar jarak jauh, dan merasa terpaksa, jika sarana dan prasarana yang kurang memadai di rumah (Utomo, 2021). Tidak hanya anak reguler saja yang merasakan kesulitan ketika proses pembelajaran dilaksanakan secara daring, hal ini juga berlaku bagi anak berkebutuhan khusus yang bersekolah. Kesulitan belajar Anak Berkebutuhan Khusus yang dimaksud kesulitan dalam bentuk kegiatan menyimak, berbicara, membaca, menulis, menalar, dan berhitun. Arti dari pendapat diatas dapat diartikan bawah sebelum pandemic anak berkebutuhan khusus sudah merasa kesulitan dalam hal membaca, menulis, dsbnya, apalagi di masa pandemi covid-19 sulit untuk anak berkebutuhan khusus untuk beradaptasi dengan proses pembelajaran dilakukan secara daring. Anak berkebuhan memiliki beberapa tipe yakni tunagrahita, tunanetra, tunatunggu, tunadeksa, dan slow learner (Amallia \& Unaenah,2018; Nisa, 2018). Slow leaner memiliki kesulitan belajar yang tidak tampak ketika satu ruangan dengan anak reguler. Kesulitan belajar anak slow leaner yakni marah yang tidak stabil, bahasa yang sulit dipahami, pembelajaran yang sulit, dan anak slow learner biasanya memakan waktu yang lebih lama dibandingkan anak reguler lainya untuk memahami proses pembelajaran di sekolah. Kesulitan belajar anak slow learner yakni lambatnya proses belajar, kurang konsentrasi dalam belajar, dan kurang perhatian dalam belajar matematika dari lingkungan sekitar. Anak slow learner harus menghadapi beberapa masalah belajar, seperti: kesulitan menguasai konsep abstrak, memiliki keterbatasan berbicara, memiliki motivasi belajar yang rendah, membutuhkan waktu lebih lama untuk mempelajari suatu pelajaran daripada anak biasa, pembelajaran yang harus dilakukan berkali-kali agar dapat memahami. Artinya anak slow learner yang memiliki berkomunikasi kurang bagus dan sulit untuk memahami yang sesuatu yang sulit yang menyebabkan anak slow learner kesulitan ketika proses pembelajaran dimulai apalagi dimasa pandemic covid-19. (Darimi, 2018; Fatimah, 2018; Metikasari, 2019b ;Rosdianah, 2019).

Selama pandemic covid-19 guru merupakan pendidik yang memiliki peran penting dalam proses pembelajaran, karena proses pembelajaran yang dilakukan secara daring sulit untuk anak murid memahami materi di kelas. Beberapa penelitian yang sudah dilakukan mendapatkan beberapa faktor yang menjadi peran guru didalam kelas yakni guru mempersiapkan proses pembelajaran seperti RPP, Metode Pembelajaran, Silabus. Selanjutnya, pelaksanaan pembelajaran yang diterapkan oleh guru harus sesuai dengan anak slow learner, artinya ketika proses pembelajaran berlangsung anak slow learner membahas topik, waktu, dan ruang yang sama dengan anak reguler lainnya. Terakhir melakukan evaluasi untuk proses pembelajaran selanjutnya untuk anak slow learner (Armeth \& Al, 2019; Aziz, 2016; Khiyarusoleh 2020; Pramitasari 2019). Dapat simpulkan bahwa guru harus mempersiapkan, dan memberikan layanan kepada anak slow learner agar memiliki rentang materi yang sama dengan anak reguler lainnya meski proses pembelajaran dilakukan secara daring.

Proses pembelajaran daring selain guru, orang tua juga mempunyai peran penting. Peran orangtua dalam pembelajaran adalah memberikan pembelajaran di rumah untuk anak slow learner, memberikan semangat dan motivasi belajar.dan melihat perkembangan anak di sekolah. Artinya orangtua bekerja sama dengan guru untuk melihat perkembangan di sekolah baik akademik, dan perilaku anak slow learner, membentuk tim belajar dalam keluarga, membentuk jam belajar di rumah, dan membuat suasana nyaman untuk belajar. (Khiyarusoleh, 2020; Ningrum, 2018; Nur aisyannaba, 2017). 
Hasil penelitian yang di lakukan bahwa ada 6 Anak berkebutuhan khusus mengalami kesusahan dalam belajar mata pelajaran matematika, yaitu tidak ada RPP untuk menjelaskan metode yang harus digunakan anak slow learner, dua anak slow learner kesulitan saat guru menggunakan metode diskusi dan presentasi, dan tiga anak slow learner memahami apa yang mengandung rumus. dan materi semu, keempat anak slow leaner sulit memahami bahasan dan tulisan yang diajarkan oleh guru dikelas, kelima belum ada media pembelajaran yang baik untuk anak slow leaner. Sehingga dapat disimpulkan bahwa kesulitan belajar matematika anak slow leaner di karenakan bahwa masih kurangnya fasilitas yang digunakan anak slow leaner didalam kelas. Sehingga dapat disimpulkan bahwa kesulitan belajar matematika anak slow leaner di karenakan bahwa masih kurangnya fasilitas yang digunakan anak slow leaner didalam kelas, dengan menggunakan subjek slow leaner di SMA (Nur Sakiinatullaila, 2020). Hasil penelitian ini mendapatkan bahwa guru harus menyusun RPP dan setiap RPP harus di modifikasi yang sesuai dengan anak slow leaner, guru harus memahami kesulitan belajar yang dihadapi oleh anak slow leaner selama dikelas. Dapat disimpulkan bahwa dalam proses pembelajaran anak slow leaner dibutuhkannya guru dan guru pendamping anak selama dikelas, dan guru harus bisa memodifikasi RPP yang sesuai dengan anak slow leaner, dengan menggunakan subjek slow leaner di SD (Hadi, 2017).

Hasil penelitian mengatakan bahwa peran orangtua adalah sebagai pendamping utama dirumah, sebagai fasilitator, sebagai guru pendamping dirumah ketika belajar. Dan peran guru pendamping adalah sebagai guru yang memberi semangat kepada anak, sebagai guru yang memberitahu kepada guru mata pelajaran bahwa anak tidak paham materinya. Dapat disimpulkan bahwa peran orangtua dan guru sangatlah berpengaruh kepada belajar anak baik dirumah maupun disekolah, dengan menggunakan subjek slow leaner di SD (Khiyarusoleh, 2020). Hasil penelitian yang didapatkan bahwa guru harus mempunyai perencanaan pembelajaran matematika dengan pertimbangan kemampuan anak dan keahlian anak, proses pembelajaran anak dikelas dibutuhkannya guru pendamping agar ketika guru matematika menjelaskan guru pendamping dapat membantu si anak, adanya evaluasi pembelajaran dalam mata pelajaran terutama mata pelajaran matematika. Dapat disimpulkan bahwa guru harus memodifikasi soal untuk anak slow leaner, dan penyerdehanaan soal sesuai dengan kemampuan anak, dengan menggunakan subjek slow learner di SMA (Irawan \& Febriyanti, 2018). Dari penelitian-penelitian sebelumnya dapat dilihat bahwa belum adanya peran guru dan orangtua dalam mengatasi kesulitan belajar anak slow learner di masa pandemic-19

Jabaran tersebutlah yang menjadi salah satu alasan penelitian yang bertujuan untuk mengetahui lebih dalam mengenai peran orang guru dan orangtua dalam membantu mengatasi kesulitan belajar matematika anak slow leaner, dan memiliki manfaat penelitian yakni Dengan adanya penelitian ini, maka diharapkan penelitian ini dapat bermanfaat sebagai acuan dalam pengembangan pendidikan matematika khususnya pada peran orang guru dan orangtua dalam mengatasi anak slow leaner dalam pembelajaran yang dilakukan secara daring.

\section{METODE}

Metode yang digunakan adalah metode deskriptif kualitatif. Penelitian kualitatif deskriptif, yang menampilkan latar belakang, peristiwa, dan objek secara keseluruhan, kemudian dilanjutkan dengan menganalisis dan mengumpulkan data, penelitian lebih terfokus dan mengurangi topik (Shidiq \& Choiri, 2019). Penelitian kualitatif adalah penelitian yang memiliki proses agak kompleks, karena penelitian yang di pilih untuk meneliti kualitatif mempunyai karakteristik yang bertujuan untuk menggali pengalaman partisipan peristiwa. (Heriyanto, 2018).

Alur penelitian peneliti yakni Peneliti melakukan telaah kepustakaan dan studi pendahuluan. Pada tahap ini peneliti melakukan telaah kepustakaan dengan mengumpulkan berbagai referensi yang relevan terkait masalah yang akan di teliti oleh peneliti. Peneliti mendatangi langsung tempat penelitian yang akan dilaksanakan untuk mengumpulkan fakta-fakta mengenai masalah yang akan diteliti. Dari Hasil telaah kepustakaan dan studi pendahuluan peneliti mulai menyusun fokus masalah penelitian, dengan melihat fakta-fakta di lapangan yang dirasa perlu menjadi fokus penelitian. Setelah menentukan fokus masalah penelitian, peneliti mulai menentukan sampel penelitian. Subjek penelitian yang dilakukan peneliti ada tiga yaitu guru mata pelajaran matematika, orangtua anak slow leaner, dan kepala sekolah yang di laksanakan di SMP Negeri 233 Kota Jakarta Timur. Pengambilan sampel dengan teknik purposing sampling. Setelah menentukan fokus penelitian, peneliti mulai mengumpulkan data. Teknik pengumpulan data yang digunakan peneliti adalah observasi lapangan, wawancara, dan penelitian kepustakaan. Analisis data menggunakan tiga tahap, yaitu: tahap reduksi data, tahap penyajian data, dan tahap penarikan kesimpulan. Hasil penelitian diperoleh dari data yang dikumpulkan dan dianalisis dari observasi, wawancara, dan angket. Untuk mengetahui kemungkinan hasil penelitian dapat dialihkan ke bidang lain, maka peneliti melakukan uji transferabilitas. Untuk mengetahui reliabilitas peneliti menggunakan uji 
dependibilitas. Untuk mengetahui apakah hasil benar peneliti menggunakan uji komformitas. Pada tahap penyusunan kesimpulan peneliti menyimpulkan hasil pembahasan, yang diperkuat dengan telaah kepustakaan. Pada tahap penyusunan saran peneliti didasari oleh kekurangan peneliti yang dilakukannya, sehingga memudahkan peneliti lain untuk melakukan penelitian lebih lanjut terkait penlitiannya.

Metode penelitian yang digunakan merupakan pendekatan penelitian kualitatif dengan metode deskriptif. Strategi dan tipe penelitian kualitatif dengan deskriptif memiliki sifat seperti penelitian kualitataif, bersifat heuristik artinya dengan deskriptif akan ditemukan alasan suatu masalah atau isu penelitian (Sugiyono, 2017). Teknis analisi data yakni memeriksa keabsahan data penelitian kualitatif, peneliti melakukan uji kredibiltas dengan menggunakan analisis data penelitian yang menggunakan model (Sugiyono, 2017) dilakukan sebelum penelitian di lapangan, dan saat penelitian di lapangan. Saat penelitian di lapangan menjadi tiga yaitu: Reduksi Data, Penyajian Data, Penarikan Kesimpulan.

\section{HASIL DAN PEMBAHASAN}

\section{Hasil}

Hasil penelitian yang bertujuan menganalisis peran guru dan orangtua dalam mengatasi kesulitan belajar anak slow learner, memperoleh data yang berkaitan dengan peran guru, peran orangtua, dan peran kepala sekolah. Beberapa hasil penelitian yang berkaitan dengan peran guru yakni pertama, Peran guru berkaitan dengan merancang proses pengajaran. Berdasarkan hasil wawancara guru, guru merancang RPP yang sementara yang disesuaikan selama masa pandemic covid-19, RPP sudah siap sebelum ajaran tahun baru dimulai untuk mempermudah guru ketika pelaksanaan pembelajaran dimulai, karena tidak ada perbedaan RPP untuk anak slow learner dengan anak reguler lainnya membuat guru dapat melihat RPP yang sama ketika proses pembelajaran berlangsung. Silabus sudah ada dan sudah disiapkan oleh kepala sekolah untuk seluruh guru mata pelajaran, karena silabus sudah ada ketetapan dari pemerintah. Media yang digunakan oleh guru mata pelajaran merupakan video pembelajaran, diharapkan dengan adanya video pembelajaran anak slow learner dapat memahami pembelajaran di kelas. Jadi perencanaan proses pembelajaran yang dilakukan oleh guru sudah di sesuaikan dengan kondisi dilapangan. Hal ini tentu sudah dipikirkan mengenai pengaruh persiapan proses pengajaran untuk anak slow learner oleh guru mata pelajaran. Persiapan guru mata pelajaran dapat terlihat dari pemahaman guru mengenai karakteristik anak slow learner, perencanaaan pembelajaran matematika yang disusun dan dituangkan melalui perencanaan proses pembelajaran yang dapat dikatakan baik. Namun dalam proses perencanaan pembelajaran matematika masih dilakukan oleh guru mata pelajaran, karena harus di sesuaikan dengan kondisi anak slow learner di kelas (Armeth \& Al, 2019; Aziz, 2018; Khiyarusoleh 2020; Pramitasari 2019). Sehingga rancangan proses pembelajaran yang dibuat harus diperhatikan dengan baik untuk anak slow learner.

Kedua, Peran guru berkaitan dengan pelaksanaan pembelajaran. Berdasarkan hasil wawancara guru mata pelajaran, pelaksanaan pembelajaran yang dilakukan secara daring dan keterbatasannya siswasiswi yang membuat guru mata pelajaran memilih kegiatan pembelajaran dengan memanfaatkan aplikasi whatsapp. Didalam pelaksanaan pembelajaran guru mata pelajaran melakukan absensi untuk memastikan siswa-siswi hadir didalam kegiatan pembelajaran, setelah siswa-siswi hadir semua guru mengirimkan video pembelajaran, dan latihan soal yang dapat dikerjakan baik untuk anak reguler maupun untuk anak slow learner. Selama pengerjaan latihan soal guru memberikan fasilitas khusus anak slow learner yakni anak slow learner dapat bertanya mengenai soal, atau materi yang tidak dipahami ke guru mata pelajaran melalui personal chat whatsapp. Setelah selesai pengerjaan latihan soal, biasanya guru memberikan games berupa soal tambahan yang dikirim ke group untuk melihat pemahaman anak murid dalam materi tersebut, dan guru mewajibkan anak murid untuk menjawab games tersebut, ini dilakukan oleh guru mata pelajaran agar melatih kemampuan kepercayaan diri anak slow learner didalam kelas. Peran guru berhasil apabila guru dapat memahami kemampuan baik anak reguler maupun anak slow learner, merupakan guru yang pintar dalam membangun suasana kelas yang menyenangkan dan kondusif (Aziz, 2018). Jadi, pelaksanaan pembelajaran yang diberikan oleh guru mata pelajaran disesuaikan dengan anak slow learner agar memahami materi yang ada di kelas.

Ketiga, Peran guru berkaitan dengan tindak lanjut pembelajaran. Berdasarkan hasil wawancara guru mata pelajaran, tindak lanjut pembelajaran yang dilakukan oleh guru mata pelajaran yakni melakukan assement dalam pembelajaran dengan cara guru melakukan penilaian terhadap anak reguler maupun anak slow learner setelah kegiatan pembelajaran dikelas berakhir. Penilaian yang diberikan oleh guru mata pelajaran untuk anak slow learner dengan anak reguler lainnya berbeda, contoh jika anak reguler dihitung satu soal salah, maka untuk anak slow learner jika bisa mengerjakan dua soal saja dan benar maka dianggap sudah menyelesaikan soal dengan baik. Selain melakukan assement atau penilaian guru mata pelajaran melakukan tindak lanjut berupa KKM khusus untuk anak slow learner, artinya KKM 
yang diberikan untuk anak slow learner berbeda dengan anak reguler lainnya, jika anak reguler KKM terkecilnya 75, maka untuk anak slow learner KKM terkecilnya 50 ini dilihat dari kemampuan anak slow learner yang berbeda dengan anak reguler lainnya. Selain melakukan KKM khusus untuk anak slow learner guru mata pelajaran melakukan tindak lanjut berupa remedial. Remedial yang dilakukan oleh guru mata pelajaran untuk anak slow learner berbeda dengan anak reguler, untuk anak slow learner remedial berupa soal yang berbeda dan lebih mudah, atau mengerjakan soal kembali yang sekiranya menurut anak slow learner mudah untuk dikerjakan. Peran guru berupa evaluasi atau tindak lanjut dapat dalam bentuk apapun seperti KKM khusus, penilaian khusus, memodifikasi soal, melakukan tes atau non test untuk mengukur kepahaman anak slow learner dikelas (Aziz, 2018; rawan \& Febriyanti, 2018; Sakiinatullaila \& Priyanto, 2018). Tindak lanjut yang diterapkan oleh guru mata pelajaran tentu sangat efektif, karena dapat memberikan bantuan kepada anak slow learner agar mereka mampu mengerjakan soal lebih baik dalam meningkatkan kemampuan anak slow learner di sekolah.

Berdasarkan jabaran hasil berkaitan dengan peran guru dalam mengatasi kesulitan belajar anak slow learner dapat dikatakan sudah baik. Dengan peran guru yang baik tentu akan berpengaruh terhadap pembelajaran yang baik. Oleh karena itu, guru mempersiapkan proses pembelajaran seperti RPP, Metode Pembelajaran, Silabus. Selanjutnya, pelaksanaan pembelajaran yang diterapkan oleh guru harus sesuai dengan anak slow learner, artinya ketika proses pembelajaran berlangsung anak slow learner membahas topik, waktu, dan ruang yang sama dengan anak reguler lainnya. Terakhir melakukan evaluasi untuk proses pembelajaran selanjutnya untuk anak slow learner (Armeth \& Al, 2019; Aziz, 2016; Khiyarusoleh 2020; Pramitasari 2019). Peran guru matematika yang kompeten akan menghasilkan anak slow learner yang mudah memahami materi pembelajaran di kelas (Sakiinatullaila \& Priyanto, 2018). Peran guru merupakan kunci sukses untuk anak slow learner belajar dengan baik dan dapat kemajuan sesuai dengan tujuan pencapaian pembelajaran untuk anak slow learner (Marchetti, 2019). Pernyataan ini sesuai dengan hasil penelitian yang mana peran guru mata pelajaran yang baik akan membantu anak slow learner dalam mengatasi kesulitan belajar matematika di kelas, namun pembelajaran daring membuat guru meminta bantuan kepada orangtua untuk mengawasi anak slow learner ketika pembelajaran dilaksanakan. Berikut lebih rinci mengenai peran orangtua yang akan dijabarkan sebagai berikut.

Pertama, Peran orangtua berkaitan orangtua sebagai pelindung anak. Berdasarkan hasil wawancara orangtua anak $\mathrm{ABK}$, pelindung anak yang dilakukan oleh orangtua yakni orangtua memberikan hak yang layak dalam pendidikan kepada anak slow learner mengenai sekolah maupun ketika belajar di rumah, artinya hak dalam pendidikan di sekolah, orangtua memperhatikan sekolah yang akan dimasuki anak slow learner yang sesuai dengan fasilitas yang dibutuhkan anaknya ketika di sekolah, selain fasilitas orangtua juga mengusahakan anaknya dapat di sekolah umum dengan harapan anaknya dapat bersosialisasi dengan baik di sekolah umum. Selanjutnya hak ketika belajar di rumah orangtua membentuk atau membangun rumah yang nyaman untuk anak slow learner belajar sehingga anak slow learner tidak merasa tertekan ketika berada di rumah. peran orangtua merupakan pendamping utama dirumah dengan memberikan fasilitator yang sesuai dengan anak slow learner, dan membuat suasana nyaman untuk anak slow learner (Khiyarusoleh, 2020). Orang tua perlu melihat fasilitas anak slow learner di sekolah agar dapat sesuai kebutuhan anaknya (Maryani, 2018). Sehingga orangtua sebagai pelindung anak dapat dikatakan baik, jika orangtua memperhatikan kebutuhan yang diperlukan anak slow learner baik di sekolah maupun di rumah.

Kedua, Peran orangtua berkaitan dengan orangtua memprioritaskan anak. Berdasarkan hasil wawancara orangtua anak ABK, memprioritaskan anak yang dilakukan oleh orangtua yakni kepedulian orangtua kepada anak slow learner mengenai perkembangan anak ketika di sekolah, dengan cara berkomunasi langsung dengan pihak sekolah mengenai perkembangan anak slow learner baik dari segi nilai, pengetahuan, dan keterampilan. Ketika proses pembelajaran yang dilakukan secara daring orangtua selalu menemani anaknya walau orangtua juga sibuk dengan perkerjaan kantor, selain menemani orangtua juga memberikan dukungan atau dorongan semangat kepada anak slow learner agar dapat aktif ketika proses pembelajaran dimulai. Orang tua perlu berkomunikasi dengan guru untuk mengetahui perkembangan belajar siswa, dan untuk menginformasikan riwayat atau kondisi anak (Maryani, 2018). Peran orangtua dapat dilakukan dalam hal pemberian informasi tentang perkembangan anak, tugas ketika proses pembelajaran dilakukan di rumah, karena orangtua dan guru harus berkoordinasi secara intensif agar dapat memhami situasi dan perkembangan anak slow learner (Ariani, 2019). Dengan orangtua memprioritaskan anak, orangtua dapat mengikuti perkembangan anak didalam proses pembelajaran daring.

Ketiga, Peran orangtua berkaitan dengan orangtua sebagai pendidik. Berdasarkan hasil wawancara orangtua anak ABK, sebagai pendidik yang dilakukan oleh orangtua yakni orangtua memberikan latihan soal tambahan kepada anak slow learner ketika proses pembelajaran dari sekolah selesai. Orangtua memberikan latihan soal tambahan apabila kondisi anak slow learner tidak merasa lelah, 
dan biasanya orangtua memberikan latihan soal tambahan kepada anak slow learner yakni sebanyak dua sampai lima soal, ini dilakukan oleh orangtua untuk mengukur kepahaman anak slow learner dalam pembelajaran matematika. Selain memberikan latihan soal tambahan, orangtua biasanya menjelaskan ulang materi matematika yang tidak dipahami oleh anak slow learner, jika orangtua tidak paham dengan materi tersebut, biasanya orangtua akan mencarikan materi tersebut melalui media youtube atau ke aplikasi belajar seperti zenius. Peran orangtua yakni membantu anak ketika mengerjakan tugas sekolah dan membimbing dalam belajar anak slow learner. Orangtua perlu mendampingi kegiatan belajar anak di rumah agar dapat memantau perkembangan belajar anak. Orangtua juga dapat mengetahui kesulitan belajar anak dan dapat membantu mengatasinya. Pada umumnya seorang anak akan merasa lebih nyaman dalam belajar jika didampingi oleh orangtua (Ariani, 2019; Khiyarusoleh, 2020; Maryani, 2018). Sehingga orangtua sebagai pendidik merupakan hal penting dalam mengatasi kesulitan belajar anak slow learner, karena dengan orangtua menjadi pendidik membuat anak slow learner tidak merasa sungkan ketika tidak memahami materi pembelajaran.

Keempat, Peran orangtua berkaitan dengan orangtua sebagai sumber data. Berdasarkan hasil wawancara orangtua anak ABK, sebagai sumber data yang dilakukan oleh orangtua yakni orangtua mengetahui kondisi anak slow learner baik dalam maupun dari luar anak slow learner. orangtua anak ABK mengatakan bahwa anaknya sering emosi yang tidak stabil ketika ia merasa bosan atau sudah tidak mau mengerjakan sesuatu yang tidak ia inginkan. Orangtua anak ABK juga mengatakan bahwa pertama kali mengetahui jika anaknya termasuk Anak Berkebutuhan Khusus tipe slow learner ketika anaknya berumur 10 tahun saat itu guru kelasnya mengatakan bahwa ia memiliki keterlambatan belajar dari pada anak reguler lainnya, dan menyarankan kepada orangtua anak ABK untuk melakukan test IQ atau test karakteristik anak, setelah melakukan test kepada anaknya dan mengetahui hasilnya, orangtua anak ABK memutuskan tindakan lanjutan yang terbaik untuk anaknya dalam pelaksanaan pembelajaran, pendidikan, dan maupun keperluan yang dibutuhkan anaknya. Kewajiban orangtua adalah bertanggung jawab penuh terhadap anak, bila dikaitkan dengan kesulitan belajar dan tanggung jawab orangtua terhadap anak, menghubungi dokter atau mendatangi dokter untuk diagnosis awal sangat penting bagi orangtua untuk mengatasi kesulitan belajar anak slow learner (Maryani, 2018). Orangtua yang mengetahui kondisi anak baik secara dalam maupun luar dapat membantu kinerja guru selama proses pembelajaran dilakukan, dan dapat mengetahui langkah yang baik untuk mengatasi kesulitan belajar anak slow learner (Aziz, 2016). Jadi dengan orangtua mengetahui kondisi anak merupakan salah satu langkah yang baik untuk mengatasi kesulitan belajar anak slow learner.

Berdasarkan jabaran hasil penelitian yang berkaitan dengan peran orangtua dalam mengatasi kesulitan belajar anak slow learner dapat dikatakan sudah cukup baik. Dengan peran orangtua yang baik tentu akan berpengaruh terhadap pembelajaran anak slow learner ketika di rumah. Peran orangtua dalam pembelajaran adalah memberikan pembelajaran di rumah untuk anak slow learner, memberikan semangat dan motivasi belajar.dan melihat perkembangan anak di sekolah. Artinya orangtua bekerja sama dengan guru untuk melihat perkembangan di sekolah baik akademik, dan perilaku anak slow learner, membentuk tim belajar dalam keluarga, membentuk jam belajar di rumah, dan membuat suasana nyaman untuk belajar. (Khiyarusoleh, 2020; Ningrum, 2018; Nur aisyannaba, 2017). Orang tua perlu melihat fasilitas anak slow learner di sekolah agar dapat sesuai kebutuhan anaknya (Maryani, 2018). Pernyataan ini sesuai dengan hasil penelitian yang mana peran orangtua yang baik akan membantu anak slow learner dalam mengatasi kesulitan belajar matematika di rumah, namun pembelajaran daring membuat kepala sekolah ikut berpartisipasi didalam mengatasi kesulitan belajar. Berikut jabaran peran kepala sekolah dalam mengatasi kesulitan belajar anak slow learner.

Pertama, Peran kepala sekolah sebagai educator. Berdasarkan hasil wawancara Kepala sekolah, sebagai educator yang dilakukan oleh kepala sekolah yakni kepala sekolah memberikan memberikan, pelatihan, dan kebijakan khusus kepada guru untuk menghadapi anak slow learner, artinya bahwa kepala sekolah memberikan bimbingan kepada guru mengenai bagaimana mengatasi anak slow learner melalui rapat, kepala sekolah juga mengikuti kegiatan pelatihan mengenai perkembangan teknologi yang sesuai dengan anak slow learner, dan kepala sekolah tidak menentukan kebijakan mengenai penerimaan murid baru untuk anak slow learner, karena sudah ketentuan dari kediknasaan mengenai penerimaan murid baru. Kepala sekolah dalam edukator sangat mempengaruhi keberhasilan sekolah. Kepala sekolah merupakan orang yang memberdayakan orang lain, mendorong produktifitas dan elastisitas, meningkatkan perencanaan kerjasama dan berbagi pengambilan keputusan dalam upaya untuk mengembangkan pembelajaran yang sesuai dengan anak slow learner (Armeth \& Al, 2019; Purwanto, 2020). Sehingga dapat dikatakan bahwa kepala sekolah mengambil posisi yang jelas dalam mendukung proses pembelajaran yang baik untuk anak slow learner.

Kedua, Peran kepala sekolah sebagai manajer sekolah. Berdasarkan hasil wawancara Kepala sekolah, sebagai manajer sekolah yang telah dilakukan oleh kepala sekolah yakni kepala sekolah dalam 
mengambil keputusan penyelenggaraan pendidikan inklusif dipikirkan secara matang dari segi fasilitas sampai kemampuan guru disekolah, dan selalu memberikan semangat baru kepada anak slow learner dan guru ketika tahun ajaran baru dimulai. Kepala sekolah juga mengawasi setiap kegiatan, dan perbuatan yang dilakukan oleh guru. Kepala sekolah telah memberikan rencana, petunjuk, serta perintah yang telah diberikan kepada guru mengenai anak slow leaner. Mengawasi guru dalam melaksanakan tugas merupakan hal yang baik dalam proses pembelajaran maupun tugas guru di luar proses pembelajaran (Ulum, 2020). Mengetahui keunggulan dan kesalahan guru akan menjadi kunci dalam pelaksanaan pembalajaran anak slow learner (Armeth \& $\mathrm{Al}, 2019$ ), artinya guru yang memiliki kekurangan atau kesalahan dapat bantu oleh kepala sekolah melalui pelatihan atau melalui diskusi bareng dengan kepala sekolah sehingga proses pembelajaran dapat berjalan dengan efektif.

Berdasarkan jabaran hasil berkaitan dengan peran kepala sekolah dalam mengatasi kesulitan belajar anak slow learner dapat dikatakan sudah cukup memuaskan. Dengan peran kepala sekolah yang berjalan dengan baik tentu akan berpengaruh terhadap pembelajaran yang baik. Kepala sekolah memiliki kekuasaan ataupun wewenang buat memusatkan seluruh komponen sekolah yang cocok dengan anak slow learner serta tanggung jawab kepala sekolah untuk membuat suasana sekolah mendukung terhadap anak slow learner. Oleh sebab itu, setiap sekolah dituntut untuk professional dalam melakukan tugasnya dengan mengingat secara baik kepala sekolah merupakan manager dan educator dalam kesuksesan proses pembelajaran anak slow learner(Armeth \& Al, 2019; Ulum, 2020). peran kepala sekolah dapat dilihat dari indicator yakni kepala sekolah sebagai administrator, kepala sekolah sebagai supervisor, dan kepala sekolah sebagai innovator (Kebijakan, 2019). Dari pendapat diatas dengan hasil penelitian yang dilakukan oleh peneliti maka dapat diketahui perbedaanya yakni jika peneliti sebelumnya kepala sekolah memberikan arahan kepada tata usaha dalam penerimaan murid baru, maka peneliti mendapatkan informasi baru yakni kepala sekolah terjun langsung untuk mengawasi penerimaan murid baru terutama untuk anak berkebutuhan khusus. Jika peneliti sebelumnya kepala sekolah memberikan bimbingan kepada guru pendamping atau guru BK baru guru pendamping tersebut memberikan arahan kepada guru mata pelajaran, maka peneliti menemukan bahwa kepala sekolah langsung memberikan arahan dan pelatihan kepada seluruh guru mata pelajaran agar mengetahui bagaimana berkomunikasi dan mengajar yang baik untuk anak slow learner.

Kelebihan penelitian ini yakni peneliti dapat terjung langsung didalam proses pembelajaran yang dilakukan secara daring, dan dapat memaparkan secara jelas dan lengkap mengenai peran guru dan orangtua dalam mengatasi kesulitan belajar anak slow learner, dan kekurangan dalam penelitian ini yakni penelitian ini tidak memberikan deskripsi yang lengkap berupa gambar didalam proses pengambilan data. Saran dalam penelitian ini adalah perlunya perhatian khusus bagi peserta didik slow learner terutama dalam proses pembelajaran daring. Hal ini dikarenakan peserta didik slow learner tidak bisa mengikuti pembelajaran seperti peserta didik regular lainnya. Saran untuk peneliti berikutnya adalah untuk menemukan pola pembelajaran daring yang lebih efektif bagi peserta didik slow learner.

\section{SIMPULAN}

Simpulan dalam penelitian ini adalah bahwa peran guru, orang tua, dan kepala sekolah sangat penting dalam mengatasi kesulitan belajar peserta didik slow learner, terutama di masa pandemic covid19. Kesulitan belajar matematika peserta didik slow learner lebih kepada proses pembelajaran. Guru harus lebih kreatif dalam memotivasi peserta didik sedangkan orang tua harus menjaga kestabilan emosi. Adapun peran kepala sekolah memberikan bimbingan kepada guru mengenai bagaimana mengatasi peserta didik slow learner, kepala sekolah juga mengikuti kegiatan pelatihan mengenai perkembangan teknologi yang sesuai dengan peserta didik slow learner..

\section{DAFTAR PUSTAKA}

Ariani, A., Wahyudi, M., \& Rugaiyah, R. (2019). InPendidikan Inklusif: Kerjasama Antar Guru Kelas, Guru Luar Biasa, Orang Tua untuk Mengoptimalkan Perkembangan Anak Berkebutuhan Khusus. International Journal for Educational and Vocational Studies, 1(5), 396-399. https://doi.org/10.29103/ijevs.v1i5.1616.

Armeth, A., \& Al, D. (2019). Pendidikan Inklusif Sebagai Gebrakan Solutif " Education for All ." 11(April), 4566.

Arnot, \& Yeland, (2020). dunia kehidupan ultimodal: Pedagogi untuk pertanyaan dan eksplorasi permainan. Jurnal Penelitian Pendidikan Anak Usia Dini,, 9(1), 124-146.

Aziz, A. N., Sugiman, S., \& Prabowo, A. (2018). Analisis Proses Pembelajaran Matematika pada Anak Berkebutuhan Khusus (ABK) Slow Learner di Kelas Inklusif. Kreano, Jurnal Matematika KreatifInovatif, 6(2), 111. https://doi.org/10.15294/kreano.v6i2.4168. 
Chang, Hong, G., Paganeli, C., Phantmvanit, P., Chang, W. J., Shieh, Y. S., \& Hsu, M. L. (2020). Inovasi pendidikan gigi di masa pandemi COVID-19. Journal international, 155. https://doi.org/10.1016/j.jds.2020.07.011.

Darimi, I. (2018). Diagnosis Kesulitan Belajar matematika Siswa slow learner Dalam Pembelajaran Aktif Di Sekolah. JURNAL EDUKASI: Jurnal Bimbingan Matematika, 2(1), 30. https://doi.org/10.22373/je.v2i1.689.

Dng, Cao, S., \& Li, H. (2020). Pembelajaran daring anak-anak kecil selama pandemi COVID-19: Keyakinan dan sikap orang tua Tiongkok. Ulasan Layanan Anak dan Remaja,118(June), 105440. https://doi.org/10.1016/j.childyouth.2020.105440.

Edwrds, S., Skoutrs, H., Rtherfrd, L., \& Cutter-Mcknze, A. (2012). Ini semua tentang Ben10TM': Keputusan bermain, kesehatan, dan keberlanjutan anak-anak di tahun-tahun awal. ,. Perkembangan dan Perawatan Anak Usia Dini Development and Care, 183(2), 280-293. https://doi.org/https://doi.org/10.1080/03004430. 2012.671816.

Fatimah, \& Dahlan, (2018). Description of Analysis of Mathematics Difficulty of Children with Special Needs (ABK) Slow Learner Class V SD Muhammadiyah Danunegaran Abstract Abstrak. Sendika Fkip Uad, 2(1), 130-136.

Hadi, F. R. (2017). Proses Pembelajaran Matematika Pada Anak Slow Learners (Lamban Belajar). Premiere Educandum: Jurnal Pendidikan Dasar Dan Pembelajaran, 6(01), 35-41. https://doi.org/10.25273/pe.v6i01.295.

Heriyanto, H. (2018). Thematic Analysis as a Method of Analyzing Data for Qualitative Research. anuva, 2(3), 317. https://doi.org/10.14710/anuva.2.3.317-324.

Hwng, G. J., Wng, S. Y., \& Lay, C. L. (2020). Pengaruh kerangka pembelajaran online berbasis regulasi sosial pada prestasi belajar siswa dan perilaku dalam matematika. Komputer dan Pendidikan. https://doi.org/10.1016/j.compedu.2020.104031.

Irawan, A., \& Febriyanti, C. (2018). Pembelajaran Matematika pada Siswa Berkebutuhan Khusus di Sekolah Inklusi. Journal of Medives: Journal of Mathematics Education IKIP Veteran Semarang, 2(1), 99. https://doi.org/10.31331/medives.v2i1.509.

Khachfe, Crour, M., Samouri, J., Salhab, H. A., Maki, , \& Fares, M. Y. (2020). Sebuah Studi Epidemiologis tentang COVID-19: Penyakit yang Menyebar dengan Cepat. Cureus, 12(3). https://doi.org/10.7759/cureus.7313.

Khiyarusoleh, U., Anis, A., Yusuf, R. I., \& Peradaban, U. (2020). Peran Orang Tua Dan Guru Pembimbing. 13(3), 238-244. https://doi.org/10.33541/jdp.v12i3.1295.

Kes, E. (2020). Efek McGurk dan persepsi ucapan audiovisual pada siswa dengan ketidakmampuan belajar yang terpapar pengajaran online selama pandemi Hipotesis matematika 144(July), 110233. https://doi.org/10.1016/j.mehy.2020.110233.

Lag-Cla, S., Folgurs-Díza, M. B., Alns-Hidalgo, M., Garca-Menndezb, D., \& Fernándz-Garcab, F. J. (2020). Investigasi efektivitas alat pembelajaran online untuk persiapan sertifikat kinerja energi. laporan energi pendidikan, 6, 609-614. https://doi.org/10.1016/j.egyr.2019.09.034.

Liu, Huang, J., \& Zou, Z. (2020). Ekspansi diri melalui Handphone dan kecenderungan kecanduan handphone di kalangan remaja: Model mediasi yang dimoderasi. Ulasan Layanan Anak dan Remaja, https://doi.org/10.1016/j.childyouth.

Marchetti, A. (2019). Konsep Sistem Layanan Penyelenggaraan Pendidikan Melalui Pendidikan Inklusif Bagi Anak Berkebutuhan Khusus. Jurnal Ilmiah Pendidikan Citra Bakti, 6, 186-195. https://doi.org/10.5281/zenodo.

Maryani, I., Kusainun, N., Fatmawati, L., Erviana, V. Y., Wangid, M. N., \& Mustadi, A. (2018). Parents' Roles in Overcoming Elementary Students' Learning Difficulties. International Journal of Evaluation and Research in Education (IJERE), 7(4), 305. https://doi.org/10.11591/ijere.v7i4.15015.

Mishra, D. T., \& Shre, D. A. (2020). Pembelajaran daring di Perguruan Tinggi selama Masa Lockdown Pandemi COVID-19. Jurnal Internasional Penelitian Pendidikan Open, August, 100012. https://doi.org/10.1016/j.ijedro.

Mkter, H. C. (2020). Dampak Covid-19 terhadap kegiatan ekonomi berbagi. Jurnal matematika Bersih. https://doi.org/10.1016/j.jclepro.2020.124782.

Ningrum, W. R. (2018). The Effect of Parenting Roles and Parenting Patterns on Learning Outcomes of State Elementary School Students (Sdn) in West Bogor District. Jurnal Pendidikan, 17(2), 129-137. http://jurnal.ut.ac.id/index.php/JP/article/view/621.

Nisa, K. et al. (2018). Karakteristik dan Kebutuhan Pembelajaran Anak Berkebutuhan Khusus dan Anak Berbakat. Abadimas Buana, 2(1), 33-40.

Nur Sakiinatullaila. (2020). Penyebab Kesulitan Belajar Matematika Anak Berkebutuhan Khusus Tipe Slow Learner Nur Sakiinatullaila Wahyu Fajar Pendahuluan Anak merupakan harta yang sangat 
berharga bagi setiap orang tua. Anak. 151-162.

Oydotun, T. D. (2020). Perubahan mendadak pedagogi dalam pendidikan didorong oleh COVID-19: Perspektif dan evaluasi dari negara berkembang. Research in Globalization, 2(June). https://doi.org/10.1016/j.resglo.

Pacia, A. (2020). Penggunaan dan Penerimaan Pembelajaran Daring Darurat oleh Mahasiswa Akibat COVID-19. Jurnal Internasional Penelitian Pendidikan https://doi.org/10.1016/j.ijedro.

Remuzi, A., \& Remuzi, G. (2020). COVID-19 dan Italia: apa selanjutnya? The Lancet. https://doi.org/10.1016/S0140-6736(20)30627-9.

Sahu, P. (2020). Penutupan Universitas Karena Penyakit Coronavirus 2019 (COVID-19): Dampak Pendidikan dan Kesehatan Mental Mahasiswa dan Staf Akademik. Cureus, 2019(4), 4-9. https://doi.org/10.7759/cureus.7541.

Sakiinatullaila, N., \& Priyanto, M. (2018). Causes of Difficulty Learning Mathematics for Children with Special Needs Slow Learner Type. Causes of Difficulty in Learning Mathematics for Children with Special Needs Slow Learner Type, 172, 14.

Samaha, M., \& Hawi, N. S. (2016). komputer dalam Perilaku Manusia Hubungan antara kecanduan smartphone, stres, kinerja akademik, dan kepuasan dengan kehidupan. Computers in Human Behavior, 57, 321-325. https://doi.org/10.1016/j.chb.2015.12.045.

Shidiq, U., \& Choiri, M. (2019). Qualitative Research Methods in the Field of Education. In Journal of Chemical Information and Modeling (Vol. 53, Issue 9). http://repository.iainponorogo.ac.id/484/1/Metode Penelitian Kualitatif Di Bidang Pendidikan.pdf.

Sugiyono. (2017). metode penelitian kuantitatif kualitatif dan $r$ \& d sugiyono pdf Click here to get file. 380 .

Ulum, M. B., Sarwoko, E., Yuniarianto, A., Pascasarjana, P., \& Malang, U. K. (2020). Kepemimpinan Kepala Sekolah Dan Kinerja Guru : Peran. 3(2), 299-307.

Utomo, K. D., Soegeng, A. Y., \& ... (2021). Pemecahan Masalah Kesulitan Belajar Siswa pada Masa Pandemi $\begin{array}{lllll}\text { Covid-19. Mimbar } & \text { Pgsd }\end{array}$ https://ejournal.undiksha.ac.id/index.php/JJPGSD/article/view/29923.

Wong, O. (2020). Manajemen pasien dengan gangguan hati selama pandemi COVID-19: pernyataan posisi Asia-Pasifik. 5(8), 776-787. https://doi.org/10.1016/S2468-1253(20)30190-4. 